DOI: $10.17516 / 1997-1370-0651$

УДК 1'17; 1'1(091)

\title{
Foundations of a Philosophical Theory of Exceptions: A Historical Perspective
}

\section{Alexey G. Zhavoronkov*}

Institute of Philosophy, Russian Academy of Sciences

Moscow, Russian Federation

Received 02.04.2020, received in revised form 27.07.2020, accepted 10.08.2020

\begin{abstract}
The article presents the largely neglected 'alternative' history of the philosophical notion of exception, from Ancient Rome till the late $19^{\text {th }}$ century, illustrated by Cicero, Leibniz, Kant, Hegel, Kierkegaard and Nietzsche. While arguing against the common narrow view on exceptions as a political concept (following Carl Schmitt and others), the analysis lays out the much-needed historical foundation for a potential broad theory of exception, still notoriously absent in modern practical philosophy. The main goal is to demonstrate that in the history of philosophy the discussion concerning exceptions was not limited to philosophy of law, encompassing many other fields like epistemology, ethics, anthropology, social and political philosophy.
\end{abstract}

Keywords: exception, practical philosophy, history of philosophy, Cicero, Leibniz, Kant, Kierkegaard, Nietzsche.

Research area: philosophy.

Citation: Zhavoronkov, A.G. (2020). Foundations of a philosophical theory of exceptions: a historical perspective. J. Sib. Fed. Univ. Humanit. Soc. Sci., 13(8), 1405-1415. DOI: 10.17516/1997-1370-0651.

(C) Siberian Federal University. All rights reserved

* Corresponding author E-mail address: outdoors@yandex.ru ORCID: 0000-0001-8362-1782 


\section{A philosophical theory of exceptions?}

Exceptions, along with norms, are an integral part of our everyday life. Any new knowledge which contradicts one's accustomed order of things, any non-typical situation, decision and action can be (in a broad sense) defined as exceptions. While exceptions can lead to confusion and at times to some dangerous decisions, they also help us to question our established ideas and worldview, thus leading to important insights and developments. ${ }^{1}$ Recent events during the pandemic of COVID-19 have once more shown us on a global scale that exceptional situations and decisions are a crucial part of our reality and understanding of the world. Still, somewhat surprisingly, modern philosophy is reluctant in dealing with this topic on a systematic basis, even though we can find some attempts in separate areas which have some history of dealing with the concept of exception, for instance in ethics ${ }^{2}$ and in philosophy of law. A coherent theory of exceptions which would neither confine itself to political agenda nor play a subservient role in the ongoing battle between different normative theories is still not in sight. In what follows, I will present some general thoughts concerning this potential theory of exception and its historical foundations.

In order to recognise a person, a case or an action as an exception, i.e. to understand that at least some part of it lies outside the norm, we have to compare the new information with the one already known to us. In the course of history, this process of comparison has gradually become more complex as the evolution of the means of communication has made new knowledge more accessible. In the modern digital era, which can rightly be called the age of comparison, this process is both simpler, because of the accessibility of information, and more complex, given the amount of knowledge available to us. Exceptions show similarities to earlier cases (in this respect, they are not com-

\footnotetext{
1 Of course, on the social and political level, exceptions can also be subject to manipulations if used to instigate ungrounded conclusions and to undermine the existing strategies and agreements.

2 See, for instance, the debate on moral exceptions in vol. 62/6 (2014) of "Deutsche Zeitschrift für Philosophie".
}

pletely foreign or opaque) without being fully identical to them.

Generally speaking, the term 'exception' can either relate to 'exceptional' people who make decisions and take actions or, more directly, to exceptional situations, decisions or actions. In the first case, the discussion about exceptions is often limited to political topics since exception as a philosophical concept can be traced to Carl Schmitt's idea of sovereign action in the state of exception. Schmitt or, less often, Friedrich Nietzsche are mostly referenced when scholars apply the term 'exception' to outstanding people who consider themselves as exceptions or who look like exceptions in the eyes of others. ${ }^{3}$ As soon as we convince ourselves to look at the problem exclusively from this angle, we forget that, in principle, any person can consider itself an exception because of its uniqueness. In the second case, exception usually plays a subordinate role in various normative theories. However, if one focuses only on (undoubtedly important) rules and principles, it is very easy to underestimate topics related to decisions and actions of each person in exceptional situations and to mechanisms of making non-standard decisions under various circumstances, not all of which are necessarily unusual.

In the coordinate system of modern social sciences, a theory of exceptions which aims to avoid the mentioned methodological traps and to present a multi-layered philosophical view of exceptions from a practical perspective finds itself at the intersection between neurobiology, theories of action, applied ethics, sociology of disaster, philosophy of law, political theories and philosophy of science. A possible method, allowing to take into account many theories and arguments from these vastly different areas, could be the anthropological approach since the latter can simultaneously take into account the biological, ethical and social perspective. Our starting point could be the idea that we should not consider exceptions as a rare privilege of the few but as an integral part of

\footnotetext{
3 In its most radical and simplified form, this view of exceptions can be easily instrumentalised for justification of political arbitrariness.
} 
the daily life and a key element of our everyday orientation.

But before undertaking the difficult task of constructing a comprehensive practical theory of exceptions, for instance, by analytically dividing exceptions into types according to the initial situation, the form of action, or its consequences, one has to understand what has been done for the analysis of exceptions as elements of human decisions and actions. Of course, in the history of Western philosophy significantly more attention has traditionally been paid to norms and rules while the concept of exception remained in the shadow, until it has found its widely recognised, but in fact very narrow philosophical niche in the $20^{\text {th }}$ century. In rare (and mostly short) dictionary articles on the notion of exception its history usually begins with Kierkegaard and Schmitt. Still, it is easy to notice that the concept of exception has been present in the history of philosophy since ancient times.

The following overview which focuses on sources and thinkers before Carl Schmitt is in no way exhaustive. Its main goal is to define some key tendencies in the past interpretations of the concept of exception as a philosophical term and to demonstrate the complexity of its still mostly neglected - history. A deeper historical understanding of the concept of exception, can, in turn, help us to think this concept beyond the traditional political framework into which it is usually placed.

\section{Ancient origins:}

\section{Cicero and the Roman law}

As far as we can judge from extant ancient sources, the concept of exception was first used in a legal context, namely in Cicero's defence of Lucius Cornelius Balbus, an influential official of Gaditan descent (i.e., a native of the Spanish town of Gades, modern Cadiz) who served under the command of Julius Caesar in Spain as a chief of military workers, which was only a starting point for his overall very successful political career. Defending Balbus' right to retain his Roman citizenship granted to him by Pompeius, Cicero battles against his opponents who seek to prove that the very procedure of obtaining Roman citizenship was il- legal in Balbus' case. The main debate revolves around a conflict between two different laws. The actions of Pompeius who granted Roman citizenship were supposedly in accord with the consular law of $72 \mathrm{BC}$ but - at least at a first glance - directly contradicted the Lex Julia according to which citizens of a community allied with Rome had the right to obtain Roman citizenship only with the permission of the community.

The key part of Cicero's argument is based on his examination of the relation between rules and exceptions in Roman law. He acknowledges that some treaties between the Romans and the ethnic groups they conquered, for instance, in case of the Germans, the Insubres, the Helvetians and the Iapydes, specifically state that representatives of these tribes cannot obtain Roman citizenship. However, Cicero adds, since there is no such exception clause in the treaty with the Gaditans, we cannot appeal to it (Balb., 14). The logic is quite simple. From the fact that there are some treaties with a clause stating the impossibility of obtaining Roman citizenship, we cannot conclude that such a clause should be presumed in other similar treaties without this explicit clause. Moreover, since these few treaties specifically classify the prohibition as an exception, there has to be a general rule according to which members of ethnic groups can obtain Roman citizenship if there is a treaty with Rome. The argument looks good per se, but it is not enough to refute the counterarguments of Cicero's opponents who refer to the law of Julius which applies to Hades as an allied community. Understanding this, Cicero takes a further step, claiming that the Gellian and Cornelian law from $72 \mathrm{BC}$ allows exceptions from Julius's law, although only those of legitimate kind which do not violate the sacred status of treaties. According to Cicero, to doubt Balbus' right to retain his Roman citizenship is not to doubt the merits of the accused (since these merits are quite obvious) but rather to dispute Pompeius' right to grant this citizenship. So why does Pompeius have this right in the case of Balbus? According to Cicero, because the text of the agreement with the Gaditans has a legitimate status but is not sacred and, thus, inviolable. The sacred 
status would require a ratification by a public decision, which was not the case for the treaty with the Gaditans (Balb., 14-15). Since only a sacred status of a treaty would not allow any exceptions, including the ones that are legally sanctioned, we can conclude that the agreement with Hades does not prevent legitimate exceptions.

It is in connection with his defence of Balbus that the famous phrase "exception proves the rule" (exceptio probat regulam) or, in its full form, "exception proves the rule in cases not excepted" (exceptio probat regulam in casibus non exceptis) is attributed to Cicero. Although Cicero himself does not use it, ${ }^{4}$ it accurately describes the first part of his argument regarding exceptions in treaties. In this concise form, the phrase has taken root in the European legal tradition ${ }^{5}$ and in the cultural tradition as a whole, gradually turning into an everyday principle applicable to conclusions, decisions and actions of any person. Even though the claim behind it, namely that the rule still stands despite the exception and, secondly, that the exception, does not undermine the rule but rather confirms it, may look flawed from a general point of view, it works for specific arguments, especially in legal cases (Holton, 2010).

\section{Leibniz:}

\section{Exceptions as a condition of justice}

One of the most prominent philosophers of the Enlightenment who paid substantial attention to the concept of exception, both in the traditional legal context and in connection with ethics, social philosophy and philosophy of religion, was Leibniz. The term 'exception' was first used in his article "The New Method of Learning and Teaching Jurisprudence" (Leibniz, 1667), published shortly after the defence of his habilitation thesis. Unlike his predecessors, Leibniz does not use the Latin

\footnotetext{
4 In the original text, Cicero's statement looks as follows: "quod si exceptio facit ne liceat, ubi non sit exceptum, ibi necesse est licere" ("And if the exception does not permit it, it should be allowed in cases when there is no exception").

5 Cf. Jones, 1729: 221. In a different form (exceptio figit regulam in non exceptis), the phrase can be found in some earlier sources, like Collins, 1617: 100. When Leibniz added the notion of exception to his theory of justice, he was dealing with a legal term commonly used in practice.
}

word exceptio in the discussion about specific laws. Instead, he turns it into a key element of a universal general theoretical (methodological) argument, according to which any exception to the rule makes the latter useless since it can no longer be trusted ("Quod si regulae habent exceptiones, frustraneae sunt, quia fidi illis non potest"). To the popular objection that there is no rule without exceptions ("Nullam regulam esse sine exceptione"), Leibniz resolutely replies: such an axiom contradicts itself, actually representing a liar paradox (Leibniz, 1667: 63).

However, in his later work "Reflections on the Common Concept of Justice" ("Méditation sur la notion commune de la justice", presumably 1702), Leibniz's opinion regarding the concept of exception takes a drastic turn, presumably because he now considers its role not only from a legal but also - long before Kant, Hegel and Kierkegaard - from a theological, ethical and social perspective. ${ }^{6}$ Contrary to his argument in "Nova methodus", Leibniz states that we need exceptions from a strict rule (jus strictum), linking the exception with the idea of equality (equitas) and piety (pietas). In this context, he criticises Hobbes and some unnamed Latin lawyers who only pay attention to strict rules to the disadvantage of the ideas of equality and piety. According to Leibniz, only the latter can provide the necessary foundation for the principles of universal justice outlined by Aristotle. Strict adherence to the strict rule without regard for equity could only lead to lawlessness (in accordance with the proverb summum jus summa est injuria, "the more law, the more injustice" $"$ ), so in justified cases we have to make an exception from it, in order to mitigate it (Leibniz, 1989: 571).

From a contemporary perspective, the flexible concept of exception proposed in "Reflections" looks much more relevant, at least in legal, ethical and social aspects. It not only helps us to explain some features of the modern legal system where exceptions can sometimes be in great abundance (for instance, in

\footnotetext{
${ }^{6}$ Unfortunately, there are no special studies on this very interesting topic. Still, we can find some important observations in Stephan Meder's book on Leibniz (Meder, 2018: 77 ff.).

7 Here, Leibniz implicitly references Cicero, since the proverb is mentioned in his work "De officiis" (I.10.33).
} 
copyright laws), but it also broadens the perspective of the discussion concerning the relationship between rules and the ever-changing reality of life. It is also important to note that Leibniz takes an important - while also necessary - philosophical step from the technical use of the concept of exception in the legal context to its broader philosophical understanding from the natural, ethical and social perspective. In later philosophical theories of exceptions, these perspectives will often intersect with each other.

\section{German Idealism:}

\section{Rationalisation and anthropological rehabilitation of exceptions}

In German idealism which concentrated on norms and moral principles, the concept of exception mostly played a marginal role. Still, this does not mean that there were no instances of using exception as a notion. The question of whether exceptions are necessary becomes part of Immanuel Kant's ethical and anthropological arguments in his late works of the 1780s and the $1790 \mathrm{~s}$, for instance in connection to the problem of deviation from general principles and laws and to the topic of pragmatic limitations of our use of reason. In the "Groundwork of the Metaphysic of Morals" (1785) and in the "Metaphysics of Morals" (1797), exception mostly means a violation of laws, moral rules or customs. In the latter work, Kant provides a key example for his analysis of the main differences between murder and execution, namely the example of a criminal (which was later inverted by Nietzsche in "Thus Spoke Zarathustra"):

Now the criminal can commit his misdeed either on a maxim he has taken as an objective rule (as holding universally) or only as an exception to the rule (exempting himself from it occasionally). In the latter case he only deviates from the law (though intentionally) [...]. In the first case, however, he rejects the authority of the law itself, which validity he still cannot deny before his own reason, and makes it his rule to act contrary to the law. His maxim is therefore opposed to the law not by way of default only (negative) but by rejecting it (contrarie) $[\ldots]$.

The reason for horror at the thought of the formal execution of a monarch by his people is therefore this that while his murder is regarded as only an exception to the rule that the people makes its maxim, his execution must be regarded as a complete overturning of the principles of the relation between a sovereign and his people [...], so that violence is elevated above the most sacred rights brazenly and in accordance with principle. Like a chasm that irretrievably swallows everything, the execution of a monarch seems to be a crime from which the people cannot be absolved, for it is as if the state commits suicide (Kant, 1991: 132; AA VI, $320^{8}$ ).

For Kant (and later for Hegel), the concept of exception is still closely related to legal issues, as was the case for Leibniz. Of course, Kant's main goal in this case is not to discuss specific issues of public law but rather to answer the central question in the discussion of the events and consequences of the French Revolution: can we consider the execution of a monarch as an ordinary murder? Continuing his line of criticism against those who directly participated in the bloody events of the French Revolution, Kant points out that a violent severance of relations between the sovereign and the people is unacceptable both from the ethical and legal point of view. His contrasting description of an ordinary crime as an exception from the rule which the perpetrator still "cannot deny before his own reason" is, in turn, connected to his argument on the consequences of the crime from an internal point of view, culminating in the famous metaphor of the inner court of conscience.

To a somewhat different line of reasoning related to exceptions belongs the question on the limitations of a pragmatic application of reason. Kant initially introduces it in the "Groundwork" and in the "Critique of Practical Reason" (1788) where the rules of exceptions (exceptivae), along with the practical rules of

8 Along with the English translation, I reference the German Academy Edition of Kant's works (Akademie-Ausgabe, AA). 
commission (praeceptivae) and omission (prohibitivae), become part of the 'quality' category of freedom regarding the concepts of good and evil (Kant, 2015: 56; AA V, 66). Realizing that people are inclined to consider themselves as an exception to any rule and, at the same time, to assume that others should not and will not do so (Kant, 1998: 34; AA IV, 424), Kant has repeatedly pointed out the role of the categorical imperative in opposing this antimoral tendency which deprives ethical maxims of all their meaning. However, realising that the need for exceptions is inherent in human nature, Kant takes a more lenient approach, differentiating between two kinds of principles universality (universalitas) that does not allow exceptions and generality (generalitas) that allows them in some, presumably inconsiderable, cases when "the practical rational principle is to meet the maxim half way" (Kant, 1998: 34$)^{9}$ while the respect for the categorical imperative is still maintained. In his "Anthropology from a Pragmatic Point of View" (1798), Kant takes a closer look at some specific manifestations of exceptions in human actions. On one occasion, he discusses the dangers of procrastination as a mechanism that impedes the moral self-improvement of a person and constantly produces new exceptions, and on another, he proves that from a pragmatic perspective, habits are generally harmful to us, with the exception of certain mechanical elements of the daily routine which he deems necessary to maintain one's health (Kant, 2014: 40, 79; AA VII, 149, 186).

Like Kant, Hegel mentions exceptions primarily in the discussion on law and morality, for instance in the "Elements of the Philosophy of Right" (1820). While discussing the question of how we follow laws and traditions (in $\S 150$ ), he revisits the Kantian problem of manifestation of human egoism in the individual tendency to see oneself as an exception to the general rule. In this light, Hegel examines the relationship between the general idea of virtue and manifestations of virtue, noting that virtue not only can but also should serve as a

\footnotetext{
9 These aspects of Kant's view on exceptions, in comparison to Nietzsche, are discussed in more detail in Werner Stegmaier's article on ethical aspects of exceptions (Stegmaier, 2003: 127-140).
}

subject of the human disposition to distinguish oneself from others in an intelligent way, thus showing one's individual character. When separated from concrete examples, the discussion concerning virtue in general would look too abstract, and therefore unconvincing. In other words, virtue according to Hegel (and contrary to Kant) is morality in its application to the special, i.e. exceptional (Hegel, 1911: 136-137). For instance, pure respect for virtue as a law which does not take into account our individual interests cannot yield any reliable practical results in specific life circumstances..$^{10}$ Simplifying the views of Kant and Hegel on the concepts of virtue and the good, we can say that from Hegel's standpoint exceptions become a much more significant factor, as a normal practical necessity guided by our reason rather than a moral hindrance which we could reluctantly accept in some rare cases.

\section{Kierkegaard: Exception as interpretation of the universal}

Kierkegaard continues the previous discussion on the interaction between the universal and the exception. However, he raises exceptions to a higher theoretical position in comparison to Hegel, giving them priority over the general. In the afterword to "Repetition" (1843), Kierkegaard (under the pseudonym Constantin Constantius) provides a full-fledged, theologically oriented theory of exceptions:

On the one side stands the exception, on the other the universal, and the struggle itself is a strange conflict between the rage and impatience of the universal over the disturbance the exception causes and its infatuated partiality for the exception [...]. The relation is as follows. The exception also thinks the universal in that he thinks himself through; he works for the universal in that he works himself through; he explains the universal in that he explains himself. Consequently, the exception explains the universal and himself, and if one

${ }^{10}$ More on the differences between Kant and Hegel on the topic of virtue, see in Allen Wood's study on Hegel's ethics (Wood, 1990: 214-215). 
really wants to study the universal, one only needs to look around for a legitimate exception; he discloses everything far more clearly than the universal itself. The legitimate exception is reconciled in the universal; basically, the universal is polemical toward the exception, and it will not betray its partiality before the exception forces it, as it were, to acknowledge it. If the exception does not have this power, he is not legitimized [...] (Kierkegaard, 1983: 226-227).

In Kierkegaard's interpretation, exception becomes the basis of the universal. The dialectical nature of the struggle between the universal and the exception is manifested in the simultaneous presence of sympathy and antipathy, a combination of impatient anger and "infatuated partiality". An 'unjustified' exception, unlike a justified one, does not try to force the general to express its addiction and sympathy for the exception, but simply wants "to bypass the universal" without fighting it (Kierkegaard, 1983: 227), that is, it refutes the active, agonal principle of interaction with the universal. This also means that only due to its struggle with exception the universal can look at itself from the outside and interpret itself, thereby entering our individual consciousness. ${ }^{11}$ In "Either/ Or" (1843), Kierkegaard gives a more concise existential definition of legitimate exceptions, stating that only these exceptions can suffer from the fact that they are exceptions. In particular, only an exceptional person (for instance, a poet) who has gone through suffering is able to understand that each person is both an exception and part of the universal, thus finding reconciliation with his own existence (Kierkegaard, 1987: 297).

In Kierkegaard (and later in Nietzsche), the elevation of the status of exception to a key

\footnotetext{
${ }^{11}$ For a more in-depth analysis of Kierkegaard's position, see the monograph of Raphael Benjamin Rauh (Rauh, 2016: 174 182). Unfortunately, most comparisons between Kierkegaard and Nietzsche suggested by Rauh are based on the questionable premise that Nietzsche's philosophy is essentially a form of existentialism (this explains why Rauh largely ignores the cosmological and social perspective of Nietzsche's analysis of exceptions). The idea that Kierkegaard's notion of exception gives meaning to the universal is shared by Hannah Arendt (Arendt, 2005: 174).
}

philosophical concept coincides with the increase of the status of the individual in the light of the crisis of classical systematic philosophy. The exception is no longer compelled to justify its own existence but becomes an equal and at a later point a dominant participant in the dialogue with the universal, challenging traditional concepts and ideas. And while Kierkegaard mostly concentrates on the existential topic of exceptional uniqueness of individual existence, Nietzsche paints a broader picture, bringing together many different perspectives.

\section{Nietzsche: Crisis of the universal and totality of exceptions}

In Nietzsche, one of the key critics of German idealism and systematic philosophy in general, the notion of exception has its strongest advocate, both in a performative and in a theoretical (strictly philosophical) sense. Nietzsche repeatedly calls himself an exceptional person and presents himself as such, especially in the late works. The concept of exception is a part of his criticism against theories of knowledge in German Idealism and also an important factor in his crusade against Platonic morality. Moreover, it serves as a foundation for some of Nietzsche's original concepts.

In Nietzsche's "Untimely Meditations" (1873-1876), and especially in "Human, All Too Human" (1878/1886), the word "exception' refers to outstanding types and individuals, for instance to 'free spirits', as opposed to those who are restricted by cultural rules. In aphorism 33 of the first book of "Human, All Too Human", the idea of exception is simultaneously associated with rare talented people and, most likely in an implicit polemic with Kant, with a certain 'unclean' strategy of thinking that sacrifices the whole for the sake of focusing on these exceptional individuals. According to Nietzsche, it is precisely such a strategy that is necessary to believe in the value of life (Nietzsche, 1996: 29). Here, exceptions work as a principle of limitation of perspective which is essentially inevitable for an individual, although, as Nietzsche emphasises, not every limitation is useful. Still, the need for limitations does not mean that we do not need to study any rules and 'ordinary' actions which 
stem from them. Much later, in aphorism 26 of "Beyond Good and Evil", Nietzsche laments that the serious long-term work of studying an "average" man is perhaps the most unpleasant part of the "life story of every philosopher" but also points out that this work is still necessary (Nietzsche, 2002: 27).

As we can see in "Daybreak" (1881) and in the later works and fragments, Nietzsche's focus gradually shifts from exceptional persons to exceptional actions, as examples of disobedience to tradition. In this context, he pays considerable attention to the analysis of successful and unsuccessful strategies of adapting non-standard ideas and 'exceptional' (often illegal) actions to the 'mediocre' environment ${ }^{12}$ and to the guiding voice of the mind. ${ }^{13}$ From now on, the notion of exception also plays an anthropological role since these actions are prerequisites for overcoming oneself and overstepping the boundaries of traditional epistemic and moral prejudices - while the overcoming itself is only possible for human beings and not for animals.

In "The Gay Science" (1882/1887), Nietzsche presents a cosmological view of exceptions which subsequently plays a significant role in his epistemological arguments. In aphorism 109, he states that "the astral order in which we live" is itself an exception which in turn makes possible "the exception from exceptions", namely "the development of the organic" in the general chaos of the world (Nietzsche, 2001: 109). But although exception is the basic condition for human life, people are accustomed to consider it the rule. This supposed contradiction is used by Nietzsche as one of the decisive arguments against the traditional idea of the existence of laws in nature.

\footnotetext{
12 See the example of Homeric heroes in fragment 12[186] of Nietzsche's Nachlass from 1881 (Nietzsche, 1988a: 608). See also aphorism 175 in "The Wanderer and his Shadow" (Nietzsche, 1996: 352).

13 See Nietzsche's description of the pale criminal in "Thus Spoke Zarathustra": "An image made this pale human pale. He was equal to his deed when he committed it, but he could not bear its image once he had done it. / From then on he always saw himself as the doer of one deed. I call this madness: the exception reversed itself to the essence. / A streak in the dirt stops a hen cold; the stroke he executed stopped his poor reason cold - madness after the deed I call this." (Nietzsche, 2006a: 26)
}

Since the mid-1880s, Nietzsche also studies exceptions from a social perspective, as part of his analysis of cultural, legal, and political mechanisms in community and society. The most important example is paragraph 11 of the second treatise in "On the Genealogy of Morality" (1887):

To talk of 'just' and 'unjust' as such is meaningless, an act of injury, violence, exploitation or destruction cannot be 'unjust' as such, because life functions essentially in an injurious, violent, exploitative and destructive manner, or at least these are its fundamental processes and it cannot be thought of without these characteristics. One has to admit to oneself something even more unpalatable: that viewed from the highest biological standpoint, states of legality can never be anything but exceptional states, as partial restrictions of the true will to life, which seeks power and to whose overall purpose they subordinate themselves as individual measures, that is to say, as a means of creating greater units of power. A system of law conceived as sovereign and general, not as a means for use in the fight between units of power but as a means against fighting in general, rather like Dühring's communistic slogan that every will should regard every other will as its equal, this would be a principle hostile to life, an attempt to assassinate the future of man, a sign of fatigue and a secret path to nothingness (Nietzsche, 2006b: 50).

Some legal scholars think that the cited passage decisively proves that Nietzsche is a forefather of Carl Schmitt's political-legal theory of exceptions. (cf. Rudlof, 2018: 151) However, Nietzsche's subject is not sovereign action in an exceptional situation, but rather the idea of separating our thinking about justice and the legal order from the struggle between units of power. Considering such a strategy impossible, Nietzsche argues that law is not something that stands above life since it is merely an exception which limits its diversity. Thus, in Nietzsche's view, there is a whole chain of exceptions: organic life is a 
cosmological exception, and law, in turn, is an exception to this exception.

Significantly closer to Schmitt, even though only at a first glance, would be aphorism 281 in "The Wanderer and His Shadow" since it is the only instance of using the word Ausnahmezustand ("state of emergency", or "state of exception") in Nietzsche's works. The main topic is the gradual loss of power by the "offices of the king and emperor" under the non-violent, constitutional pressure of democracy. To stop this, the kings "cling with their teeth to their dignity as warlords", trying to start wars with the aim to impose "states of emergency in which that slow constitutional pressure of the forces of democracy lets up" (Nietzsche, 1996: 379). Still, Nietzsche's account of this tendency is not normative but purely descriptive, looking as a premonition of many political events of the 20th and 21st century.

Nietzsche does not mean that to have exceptional talents means to abandon all conventions and legal mechanisms. In "On Genealogy of Morality" and in several unpublished fragments of the same period, he clearly states that hatred against mediocrity is unworthy of a philosopher and even prevents him from being one. Moreover, from Nietzsche's perspective, a person who thinks of himself as exception must protect the rule at all cost (Nachlass 1887, 10[175], in: Nietzsche, 1988b: 559-560). Rather than fighting rules, we have to fight their hypocritical elements, formed by certain moral prejudices. Thus, it is clear that Nietzsche speaks of exceptional people and exceptional actions not in the narrow political or religious sense, as is the case for Carl Schmitt or for Giorgio Agamben, since his scope is not limited to those who make political decisions. According to Nietzsche, exceptions cannot be considered rules and turned into rules, which thus excludes the possibility of a permanent state of exception (including the political state of emergency). The plurality of wills to power, which constantly limit each other, is a guarantee that rules will not spontaneously change as a result of individual decisions.

\section{Conclusion}

The history of the notion of exception mirrors several major tendencies in the development of Western philosophy between the $17^{\text {th }}$ and the $19^{\text {th }}$ century. The gradual expanding of thematic scope and elevation of the theoretical status of exceptions coincided with the gradual decline in popularity of German Idealism and with the rise of the opposing (and in this sense anti-systematic) philosophical projects, like the one of Nietzsche. From now on, exceptions were even stronger associated with individualism and, from a later point onwards, with postmodernism. This development, together with the unfortunate 'Schmittian shift' in the interpretation of the notion of exception, are perhaps the main factors that deter the modern analytical philosophy and some other philosophical schools from using it for systematic purposes. Taking a broader approach and leaving behind some old prejudices against exceptions, we could understand that such a task is not only possible but also very fruitful.

\section{References}

Arendt H. (2005). What Is Existential Philosophy? In Essays in Understanding, 1930-1954: Formation, Exile, and Totalitarianism, ed. J. Kohn. New York, Schocken Books, 163-187.

Collins, S. (1617). Epphata to F.T. Cambridge, C. Legge.

Hegel, G.W.F. (1911). Grundlinien der Philosophie des Rechts [Elements of the Philosophy of Right]. Leipzig, Meiner.

Holton, R. (2010). The Exception Proves the Rule. In Journal of Political Philosophy, 18(4), 369-388.

Jones, Th. (1729). The Reports of Several Special Cases Adjudged in the Courts of King's Bench and Common Pleas at Westminster, in the Reign of King Charles II. Savoy, R. Nurr and R. Gosling.

Kant, I. (1991). The Metaphysics of Morals. Transl. by Mary Gregor. Cambridge, Cambridge University Press.

Kant, I. (1998). Groundwork of the Metaphysics of Morals. Transl. by Mary Gregor. Cambridge, Cambridge University Press. 
Kant, I. (2014). Anthropology from a Pragmatic Point of View. Transl. by R. Louden. Cambridge, Cambridge University Press.

Kant, I. (2015). Critique of Practical Reason. Transl. and ed. by Mary Gregor. Cambridge, Cambridge University Press.

Kierkegaard, S. (1983). Writings. Vol. VI: Fear and Trembling; Repetition. Ed. and transl. by Howard V. Hong and Edna Hong. Princeton, Princeton University Press.

Kierkegaard, S. (1987). Writings. Vol. IV: Either/Or. Ed. and transl. by Howard V. Hong and Edna Hong. Vol. 2. Cambridge, Cambridge University Press.

Leibniz, G.W. (1667). Nova methodus discendae docendaeque jurisprudentiae [The New Method of Learning and Teaching Jurisprudence]. Frankfurt, J.D. Zunner.

Leibniz, G.W. (1989). Philosophical Papers and Letters. Transl. and ed. by L.E. Loemker. Dordrecht/ Boston/London, Kluwer Academic Publishers.

Meder, S. (2018). Der unbekannte Leibniz: Die Entdeckung von Recht und Politik durch Philosophie [The Unknown Leibniz: Discovery of Law and Politics through Philosophy]. Köln, Böhlau.

Nietzsche, F. (1988a): Kritische Studienausgabe. Bd. 9. Nachgelassene Fragmente: Nachlaß 18801882. München/Berlin/New York, DTV/De Gruyter.

Nietzsche, F. (1988b). Kritische Studienausgabe. Bd. 12. Nachgelassene Fragmente: Nachlaß 18851887. München/Berlin/New York, DTV/De Gruyter.

Nietzsche, F. (1996). Human, All Too Human. Transl. by R.J. Hollingdale. Cambridge, Cambridge University Press.

Nietzsche, F. (2002). Beyond Good and Evil: Prelude to the Philosophy of the Future. Transl. by Judith Norman. Cambridge, Cambridge University Press.

Nietzsche, F. (2001). The Gay Science. Transl. by J. Nauckhoff. Cambridge, Cambridge University Press.

Nietzsche, F. (2006a). Thus Spoke Zarathustra. Transl. by A. del Caro. Cambridge, Cambridge University Press.

Nietzsche, F. (2006b). On the Genealogy of Morality. Transl. by C. Diethe. Cambridge, Cambridge University Press.

Rauh, R.B. (2016). Modulationen der Einsamkeit: Theorien der Ausnahme als Moralkritik bei Sören Kierkegaard und Friedrich Nietzsche [Modulations of Loneliness: Theories of Exception as Moral Criticism in Søren Kierkegaard and Friedrich Nietzsche]. Freiburg/München, Karl Alber.

Rudlof, M. (2018). Das Gesetz zur Strafbarkeit der geschäftsmäßigen Förderung der Selbsttötung [The Law Against Commercial Promotion of Suicide]. Berlin/Boston, De Gruyter.

Stegmaier, W. (2003). Mit Ausnahmen umgehen: Zur Praxis der ethischen Orientierung [Dealing with Exceptions: On the Practice of Ethical Orientation]. In Die Ausnahme denken. Festschrift zum 60. Geburtstag von Klaus-Michael Kodalle, hg. von Claus Dierksmeier, Bd. 1. Würzburg, Königshausen \& Neumann, $127-140$.

Wood, A. (1990). Hegel's Ethical Thought. Cambridge, Cambridge University Press. 


\title{
Основания философской теории исключения:
}

\section{историческая перспектива}

\section{А.Г. Жаворонков}

Институт философии РАН

Российская Федераџия, Москва

\begin{abstract}
Аннотация. Статья посвящена рассмотрению в значительной степени забытой «альтернативной» истории философского понятия исключения, начиная с Древнего Рима и до конца XIX века, на примере Цицерона, Лейбница, Канта, Гегеля, Кьеркегора и Ницше. Приводя доводы против узкого (ориентированного на работы Карла Шмитта) взгляда на исключение как на политический термин, автор намечает контуры историко-философского фундамента, необходимого для новой, широкой теории исключений, пока отсутствующей в современной практической философии. Основная цель исследования - показать, что в истории философии обсуждение исключений не ограничивалось философией права и охватывало многие другие области, в том числе эпистемологию, этику, антропологию, а также социальную и политическую философию.
\end{abstract}

Ключевые слова: исключение, практическая философия, история философии, Цицерон, Лейбниц, Кант, Кьеркегор, Ницше.

Научная специальность: 09.00.00 - философские науки. 